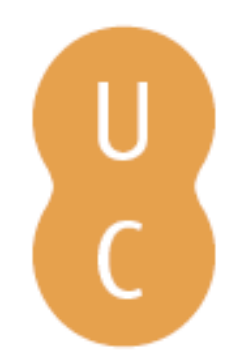

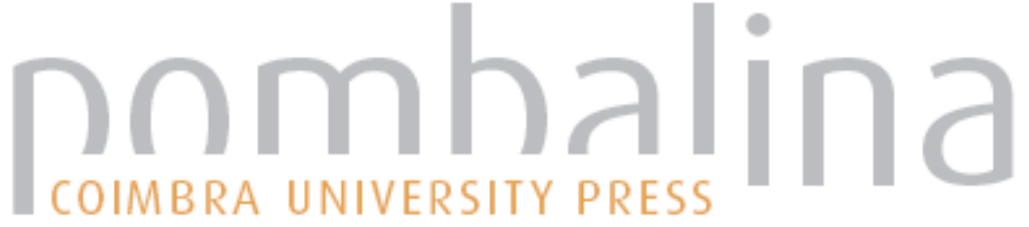

\section{Verdade e Verosimilhança na épica camoniana}

\author{
Autor(es): $\quad$ Castro, Aníbal Pinto de
}

Publicado por: Imprensa da Universidade de Coimbra

URL

persistente: URI:http://hdl.handle.net/10316.2/30747

DOI: $\quad$ DOI:http://dx.doi.org/10.14195/978-989-26-0569-2_7

Accessed : $\quad$ 26-Apr-2023 13:52:38

A navegação consulta e descarregamento dos títulos inseridos nas Bibliotecas Digitais UC Digitalis, UC Pombalina e UC Impactum, pressupõem a aceitação plena e sem reservas dos Termos e Condições de Uso destas Bibliotecas Digitais, disponíveis em https://digitalis.uc.pt/pt-pt/termos.

Conforme exposto nos referidos Termos e Condições de Uso, o descarregamento de títulos de acesso restrito requer uma licença válida de autorização devendo o utilizador aceder ao(s) documento(s) a partir de um endereço de IP da instituição detentora da supramencionada licença.

Ao utilizador é apenas permitido o descarregamento para uso pessoal, pelo que o emprego do(s) título(s) descarregado(s) para outro fim, designadamente comercial, carece de autorização do respetivo autor ou editor da obra.

Na medida em que todas as obras da UC Digitalis se encontram protegidas pelo Código do Direito de Autor e Direitos Conexos e demais legislação aplicável, toda a cópia, parcial ou total, deste documento, nos casos em que é legalmente admitida, deverá conter ou fazer-se acompanhar por este aviso.

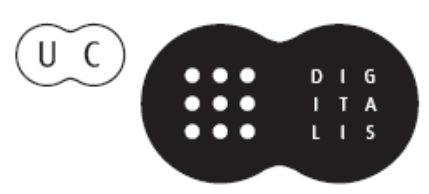




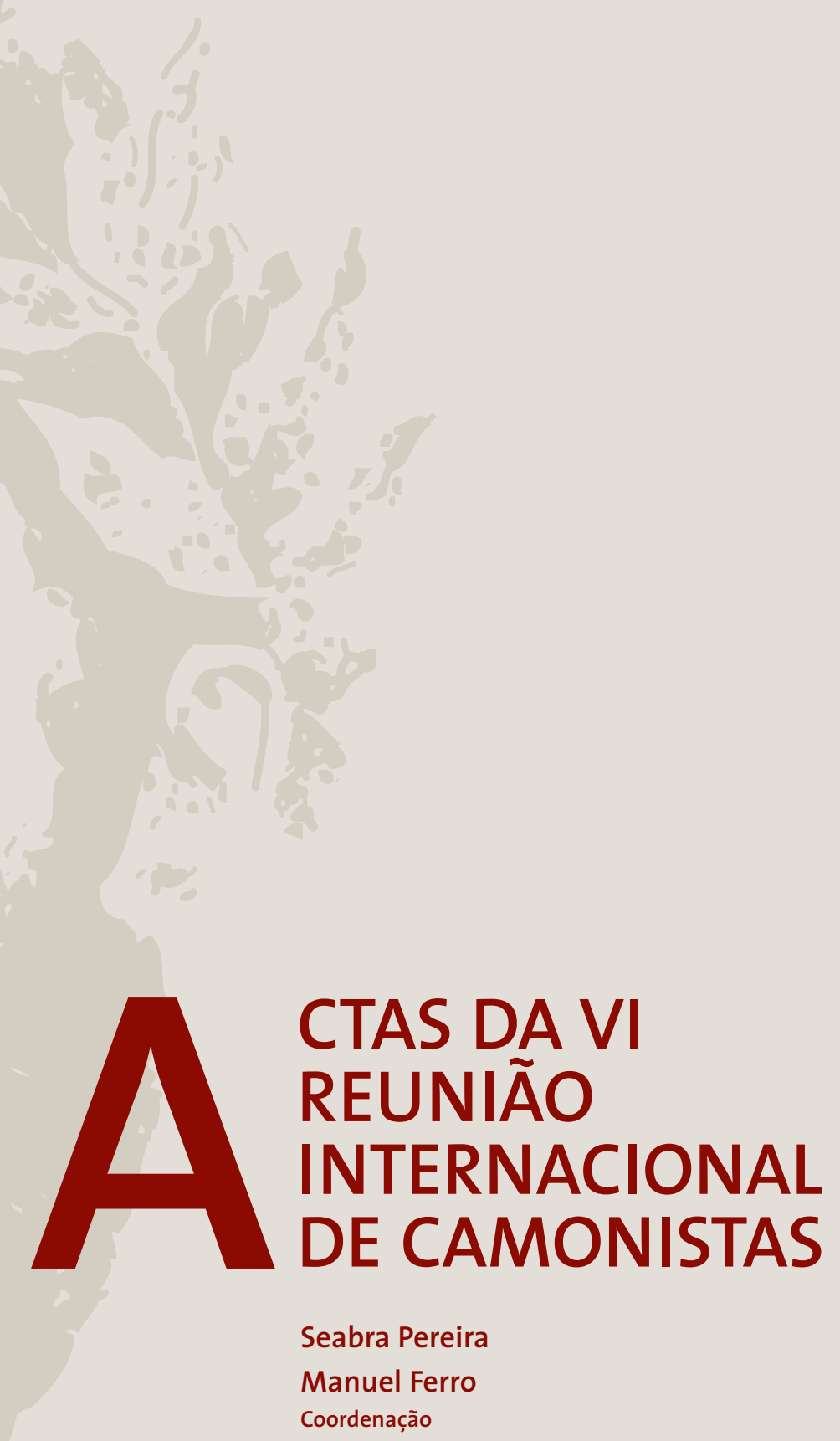




\section{Aníbal Pinto de Castro}

Universidade de Coimbra

\section{VERDADE E VEROSIMILHANÇA NA ÉPICA CAMONIANA}

Julgo não ser hoje novidade para ninguém que entre as multímodas formas da cultura camoniana se inclui - e em lugar náo despiciendo! - um conhecimento muito profundo e pormenorizado do código poético vigente no seu tempo. Precisamente por isso lhe foi tão fácil, quase diria tão aliciante (e bem dentro de uma convicta consciência da sua capacidade de criação e do seu ecletismo estético de mago verbal) infringir os seus ditames, adequar as suas regras às pulsóes da vis criadora e contribuir assim para a sua renovação, dando novo alento à dinâmica que em todos os períodos marca de maneira indelével o sistema literário, no seu permanente fieri.

Gostaria de, nesta breve intervenção, e apenas em jeito de apontamento, que nem o tempo dá para mais, nem os desconcertos da fortuna me permitiriam aprofundar devidamente o problema, trazer por minha vez uma achega ao melhor conhecimento da questão, no que toca ao uso que fez do conceito aristotélico de verosímil, tendo sobretudo em vista sustentar o primado da verdade como base essencial ao objecto que manifesta no seu discurso poético.

É conhecida a profissão de verdade que, acerca do conteúdo do Poema, Camóes faz, logo na dedicatória d' Os Lusiadas a D. Sebastiáo:

"Ouvi, que não vereis com vãs façanhas,

Fantásticas, fingidas, mentirosas,

Louvar os vossos, como nas entranhas

Musas, de engrandecer-se desejosas:

As verdadeiras vossas são tamanhas

Que excedem as sonhadas, fabulosas, Que excedem Rodamonte e o vão Rugeiro

E Orlando, inda que for a verdadeiro" 
E prossegue, contrapondo aos heróis imaginários das epopeias ferraresas, as personagens, em carne e osso, da História de Portugal.

Este respeito pela verdade, assim solenemente proclamado em lugar estratégico, pelo narrador que dá voz ao próprio autor literário, aparecerá, com significativa frequência, na boca do Gama, quando investido na função de narrador homo- ou autodiegético.

Assim, quando, para satisfazer o pedido do Rei de Melinde, inicia a história da grão genealogia da grei portuguesa, náo deixa de acentuar a verdade do que vai contar, para se escusar a qualquer reparo suscitado pelo facto de estar a louvar glórias próprias:

"Além disso, o que tudo enfim me obriga

É não poder mentir no que disser,

Porque de feitos tais, por mais que diga,

Mais me há-de ficar inda por dizer."

$$
\text { (III, 5, 1-4) }
$$

Quando chama a atenção do seu destinatário para os trabalhos sofridos durante a viagem, volta o "ilustre Gama" a reafirmar a fidelidade do conteúdo narrado à realidade vivida, aproveitando o Poeta o ensejo para, bem no espírito do Renascimento português, pôr em confronto o saber livresco dos "antigos Filósofos" com o "Saber de experiência feito" ostentado pelo narrador:

"Se os antigos Filósofos, que andaram

Tantas terras, por ver segredos delas, As maravilhas que eu passei, passaram, A tão diversos ventos dando as velas, Que grandes escrituras que deixaram! Que influição de signos e de estrelas! Que estranhezas, que grandes qualidades! E tudo, sem mentir, puras verdades."

E quando, quase no fim deste mesmo Canto V, entra na peroração do seu longo discurso, a verdade volta a ser para o navegador/narrador a marca que diferencia os seus errores dos de Ulisses ou de Eneias e, por conseguinte, a epopeia dos Portugueses das de Homero, de Virgílio ou de Ariosto:

"Julgas agora, Rei, se houve no mundo

Gentes que tais caminhos cometessem?

Crês tu que tanto Eneias e o facundo

Ulisses pelo mundo se estendessem?

Ousou algum a ver do mar profundo,

Por mais versos que dele se escrevessem,

Do que eu vi, a poder d'esforço e de arte,

E do que inda hei-de ver, a oitava parte? 
Esse que bebeu tanto da água Aónia, Sobre que têm contenda peregrina, Entre si, Rodes, Smirna e Colofónia, Atenas, Ios, Argo e Salamina;

Essoutro que esclarece toda Ausónia, A cuja voz, altíssona e divina, Ouvindo, o pátrio Míncio se adormece, Mas o Tibre co som se ensoberbece,

Cantem, louvem e escrevam sempre extremos

Desses seus Semideuses, e encareçam, Fingindo magas Circes, Polifemos, Sirenas que co o canto à vela e remos Os Cícones e a terra onde se esqueçam Os companheiros, em gastando o loto;

Dêm-lhe perder nas águas o piloto;

Ventos soltos lhe finjam e imaginem Dos odres, e Calipsos namoradas; Harpias que o manjar lhe contaminem;

Decer às sombras nuas já passadas:

Que, por muito e por muito que se afinem

Nestas fábulas vãs, tão bem sonhadas,

A verdade que eu conto, nua e pura,

Vence toda a grandíloca escritura!"

Esta valorização da verdade histórica vivida prende-se intimamente, na épica camoniana, ao conceito e à importância da experiência, na configuração humana do herói, em perfeita sintonia, aliás, com a sinceridade vivencial do Camóes lírico, ainda que sempre condicionada à dimensão autobiográfica própria do código petrarquista tão visível no soneto Enquanto quis fortuna que tivesse, significativamente colocado, logo na edição princeps, como poema proemial das Rimas. E não pode deixar naturalmente de relacionar-se, como já demonstrei noutra ocasiáo, com um conceito de épica que, enfatizando o lado humano do herói, se serve estrategicamente das fraquezas da sua humanidade para encarecer o grau da sua mesma heroicidade. Mas nem por isso a fidelidade à história deixa de ter outras motivaçóes que não me parecem despiciendas para a hermenêutica do texto camoniano.

A íntima relação entre História e a Poesia Épica fora medularmente estabelecida na Poética aristotélica. De acordo com a teoria do Estagirita, a poesia épica mais não era do que a imitação de acçôes de homens esforçados, em verso, mediante o tratamento de um argumento próprio, e distinguindo-se da tragédia apenas por ser feita sob a forma narrativa, por utilizar um verso uniforme e por poder alongar-se sem limitaçáo de tempo.

$\mathrm{Na}$ tradução latina de Antonio Riccoboni, dizia Aristóteles: 
"Epopeia igitur tragoediam usque ad solum hunc termine consecuta est, quod sit cum sermone imitatio bonorum. In eo autem differunt, quod illa quidem metrum simplex habet, et enarratio est, pareterea longa est: haec vero quam maxime conatur sub uno solis ambitu esse aut paulisper variare, cum epopeia indefinita est tempore. Atque in hoc differt. Etiam si in primis temporibus id similiter faciebant, tum in tragoediis tum in epicis" ${ }^{1}$.

A epopeia aproximou-se da tragédia enquanto imitação de acçóes de homens notáveis pelo esforço. Essa imitação devia ser em verso e através do tratamento de um único argumento. Mas distinguia-se dela por utilizar um metro uniforme e ser uma narração. E também pela extensão, pois a tragédia procurava o mais possível limitar-se a uma revolução do sol, ou pouco mais, enquanto a epopeia era ilimitada no tempo. E nisto consistia a diferença, ainda que nos primeiros tempos, tanto nas tragédias como nas epopeias, se faziam as mesmas coisas da mesma maneira

Desta definição resultava, para além de outras consequências, situadas no plano da dispositio e da elocutio, a virtual necessidade de proceder a uma cuidadosa selecção dos factos ou das acçôes a imitar, de modo que os aspectos negativos ou apenas vulgares fossem arredados da matéria diegética estabelecida pela inventio.

Como conciliar, então, a fidelidade à verdade histórica com esta necessidade de tomar apenas como matéria épica factos excepcionais do comportamento dos heróis, preocupação, aliás, explicitamente afirmada na proposição quando, ao definir o conteúdo da epopeia, o Poeta promete cantar "as armas e os baróes assinalados" que tinham praticado feitos "mais do que prometia a força humana", bem como as "memórias gloriosas" dos reis e quantos "por obras valerosas" se tinham libertado da lei da morte?

A solução estava no recurso ao verosímil, conceito a que Aristóteles conferira, na Poética, fundamental importância como meio de poetizar a banal realidade do acontecido.

Deixando o particular à História, a Poesia devia elevar-se a um tratamento da realidade já situado no plano abstracto e do geral, e, por conseguinte, numa perspectiva mais filosófica. Para atingir esse distanciamento em relação ao factual estrito dos acontecimentos, podia (e devia!) o Poeta tratar nas suas obras, náo tanto o que acontecera, mas o que podia ter acontecido. O Poeta devia, pois, ser essencialmente um inventor de fábulas e se, por mero acaso, tratava de sucessos realmente acontecidos, fazia-o em função de uma finalidade própria e autorizado pela hipótese, sempre possível, de haver acontecimentos reais que se ajustassem ao possível, saindo assim do âmbito da realidade exterior, para alcançar o plano ficcional e imaginativo da poesia. O Estagirita levava tão longe a sua teoria que defendia peremptoriamente que o poema devia preferir o impossivel, desde que verosímil, ao possivel, caso este fosse incrível.

Esta teoria obtivera ampla divulgação no tempo de Camóes, graças à versão de Alessandro de'Pazzi, aparecida em 1536, com o título de Aristotelis Poetica per Alexandrum Paccium, Patritium Florentinum in latinum conversa, e aos numerosos

${ }^{1}$ Riccoboni, Antonio, Poetica Aristotelis Latine conversa (1587) in Compendium artis poeticae Aristotelis (1591). München, W. Fink, 1970. 
comentários que então circulavam, em especial as In Librum Aristotelis de Arte Poetica Explanationes, de Francisco Robortello, saídas em 1548 dos prelos florentinos de Lourenço Torrentini.

Ora foi justamente o recurso ao verosímil que permitiu a Camóes transcender o acidental histórico dos acontecimentos para, sem faltar à verdade e mantendo-lhes os fortes traços de humanidade indispensáveis à dimensão pedagógica que pretendia para o Poema, projectar a diegese da sua narrativa no poético universal.

Vejamos a questão um pouco mais de perto.

Começarei por sublinhar que é certamente com base na verosimilhança que o Poeta pode proceder a uma selecção dos factos a poetizar, de modo a concentrar em certos momentos da acção acontecimentos ou figuras que, sendo verdadeiras, lhe podiam por esse recurso acumular uma carga épica mais intensa; ou entáo de modo a conciliar ou fundir os vários planos diegéticos do poema, para assim poder inserir no discurso formas de conteúdo simbólico onde a mitologia e o mito, como é sabido, assumirão valores fundamentais que, nem por imaginosos, se vistos à luz da racionalidade factual, póem em causa a verdade fundamental da matéria narrada e dos significados que lhe são ínsitos.

Assim se compreende, por exemplo, a pouca atenção que o narrador presta à parte da viagem que decorre entre Lisboa e a Angra de Santa Helena ou a nenhuma atenção concedida à viagem de regresso, apesar de ter superado, em dificuldades, a de ida. Como por esse modo se explica a total obliteraçáo da figura do Infante D. Henrique, apesar de consagrado desde Zurara como principal herói dos Descobrimentos, através de uma importante série de textos panegíricos. Apenas se lhe refere, muito de passagem, como descobridor das Ilhas do Atlântico:

"Assi fomos abrindo aqueles mares,

Que geração algũa não abriu,

As novas Ilhas vendo e os novos ares

Que o generoso Henrique descobriu"

$$
(\mathrm{V}, 4,4) \text {. }
$$

A própria organização estrutural do poema, através da criação de uma ordem narrativa que, embora artificial, permitia a obtenção de uma estrutura poética diferente da simples organização factual própria do relato histórico, se obtém pelo recurso ao verosímil.

Era, afinal, essa nova ordem artificial que lhe permitia toda uma série de metamorfoses dos factos históricos em ficção poética. Sem lhes alterar a marca profunda da realidade humana vivida, tão importante para a sua definição do herói, e sem lhes diminuir o grau de credibilidade que, contribuindo também para aumentar a dimensão épica do texto, assumia fundamental relevância para o cumprimento da função de pedagogia cívica, que, nos termos da teoria horaciana do utile et dulce, cabia à obra literária.

Vejamos, ainda que em síntese, alguns exemplos.

A transformação da verdade real em verosímil poético serviu não poucas vezes a Camóes para dramatizar a acção narrativa e para enriquecer o épico graças ao aproveitamento do lírico e do dramático. O caso do Adamastor é talvez o exemplo mais significativo deste processo. 
Tanto Barros (Ásia, Década I, Livro IV, cap. III), como Castanheda (História do descobrimento e conquista da Índia pelos Portugueses, L. I, cap. III) sublinham que a passagem do Cabo da Boa Esperança pela armada do Gama se fez sem o menor sinal de tempestade e até com ruidosas manifestaçóes de alegria por parte dos marinheiros.

Diz o primeiro:

“... E posto que ali acharam negros de cabelo revolto, como os passados, estes, sem receio, chegaram aos bateis a receber qualquer cousa que lhe lançavam na praia, e per acenos começaram logo de se entender com os nossos; de maneira que houve entre eles comutação de darem carneiros a troco de cousas que lhe os nossos davam. Porém de quanto gado vacum traziam, nunca puderam haver deles uma só cabeça; parece que o estimavam; porque alguns bois mochos, que os nossos viram andavam gordos e limpos, e vinham as mulheres sobre eles com umas albardas de tábua. E em três dias que Vasco da Gama se deteve aqui, tiveram os nossos muito prazer com eles, por ser gente prazenteira dada a tanger, e bailar, entre os quais havia alguns que tangiam com uma maneira de frautas pastoris, que em seu modo pareciam bem".

\section{Refere o segundo:}

“...a gente é baça e cobre-se com peles, pelejam com azagaias de paus tostados, e cornos, e ossos de alimárias por ferros, e com pedras. Na terra há muitos alifantes e mui grandes, e assi bois que são muito mansos e gordos em extremo, e são capados, e deles não tem cornos. E dos mais gordos se servem os negros pera andar neles, e trazem-nos albardados com albardas castelhanas de tábua e sobre elas uns paus que fazem feição de andilhas e nelas andam...

E vendo a mansidão dos negros saiu em terra com os seus, e fez com eles resgate de barretes vermelhos por manilhas de marfim. E logo ao sábado vieram obra de duzentos negros entre homens e moços que trouveram doze bois, e quatro carneiros: e como os nossos foram a terra começaram eles de tanger quatro frautas acordadas a quatro vozes de musica, que pera negros concertavam bem..."

Todos sabemos como, bem ao contrário desta realidade histórica, o Gigante surge da cerração da tempestade para profetizar "Naufrágios, perdiçôes de toda a sorte / Que o menor mal de todos seja a morte" (Lus., V, 44).

Salgado Júnior ${ }^{2}$ viu, com razão, no episódio da transposição da tempestade que, naquele mesmo ponto de percurso, salteara a armada de Pedro Álvares Cabral, em 1500, a do achamento do Brasil, e na qual havia de perecer Bartolomeu Dias. Mas mais do que essa realidade alheia estaria no seu espírito a lembrança da sua própria experiência, tão presente também na elegia O Poeta Simónides falando.

A criação foi aqui uma simples transposição de uma circunstância para outra, mas casos haverá em que a realidade se vê completada com elementos imaginosos que

${ }^{2}$ Cf. "Os Lusiadas" e a viagem do Gama. O tratamento mitológico de uma realidade histórica, Porto, Clube Fenianos Portuenses, 1939. 
servem de expressão às vozes, juízos ou intençôes do Poeta ou das suas personagens. É assim que aparece o Velho do Restelo.

Compare-se a narraçáo que Barros (neste ponto mais completo do que Castanheda) dá da partida de Lisboa (Década I, Livro IV, cap. I) com as estrofes 84-104 do Canto IV e a primeira do seguinte, e não será difícil descobrir nexos evidentes de intertextualidade.

"Ao seguinte dia, que era sábado, oito de Julho, por ser dedicado a Nossa Senhora, e a Casa de muita romagem, assi por esta devoção, como por se irem espedir dos que iam na Armada, concorreu grande número de gente a ela. E quando foi ao embarcar de Vasco da Gama, os Freires da casa com alguns Sacerdotes, que da cidade lá eram idos dizer Missa, ordenaram uma devota procissão, com que o levaram ante si nesta ordem: ele, e os seus com círios nas mãos, e toda a gente da Cidade ficava de trás respondendo a uma Ladainha, que os Sacerdotes iam cantando, 'té os porem junto dos batéis, em que se haviam de recolher. Onde, feito silêncio, e todos de giolhos, o Vigairo da Casa fez em voz alta uma confissáo geral, e no fim dela os absolveu na Forma das Bulas, que o Infante D. Henrique tinha havido pera aqueles, que neste descobrimento, e conquista falecessem, (como atrás dissemos). No qual acto foi tanta a lágrima de todos, que neste dia tomou aquela praia fosse das muitas, que nela se derramam na partida das Armadas, que cada ano váo a estas partes que Vasco da Gama ia descobrir: donde com razão lhe podemos chamar praia de lágrimas pera os que vão, e terra de prazer aos que vem. E quando veio ao desfraldar das velas, que os marcantes segundo seu uso deram aquele alegre princípio de caminho, dizendo boa viagem, todolos que estavam promptos na vista deles com uma piedosa humanidade dobraram estas lágrimas, e começaram de os encomendar a Deus, e lançou juízos, segundo o que cada um sentia daquela partida. Os navegantes, dado que com o fervor da obra, e alvoroço daquela empresa embarcaram contentes, também, passado o termo de desferir das velas, vendo ficar em terra seus parentes, e amigos, e lembrando-lhes que sua viagem estava posta em esperança, e não em tempo certo, nem lugar sabido, assi os acompanharam em lágrimas, como em o pensamento das cousas, que em tão novos casos se representam na memória dos homens. Assi que uns olhando pera terra, e outros pera o mar, e juntamente todos ocupados em lágrimas, e pensamento daquela incerta viagem, tanto estiveram promptos nisso, 'té que os navios se alongaram do porto."

"E já no porto da ínclita Ulisseia

Cum alvoroço nobre e cum desejo

(Onde o licor mistura e branc areia

Co salgado Neptuno o doce Tejo)

As naus prestes estão; e não refreia

Temor nenhum o juvenil despejo,

Porque a gente marítima e a de Marte

Estão pera seguir-me a toda a parte. 
Pelas praias vestidos os soldados

De várias cores vêm e várias artes,

E não menos de esforço aparelhados

Pera buscar do mundo novas partes.

Nas fortes naus os ventos sossegados

Ondeiam os aéreos estandartes;

Elas prometem, vendo os mares largos,

De ser no limpo estrelas, como a de Argos.

Despois de aparelhados, desta sorte,

De quanto tal viagem pede e manda,

Aparelhámos a alma pera a morte,

Que sempre os nautas ante os olhos anda.

Pera o sumo Poder, que a etérea Corte

Sustenta só co a vista veneranda,

Implorámos favor que nos guiasse

E que nossos começos aspirasse.

Partimo-nos assi do santo templo

Que nas praias do mar está assentado,

Que o nome tem da terra, pera exemplo,

Donde Deus foi em carne ao mundo dado.

Certifico-te, ó Rei, que, se contemplo

Como fui destas praias apartado,

Que apenas nos meus olhos ponho o freio.

A gente da cidade, aquele dia,

(Uns por amigos, outros por parentes,

Outros por ver somente) concorria,

Saudosos na vista e descontentes.

E nós, co a virtuosa companhia

De mil Religiosos diligentes,

Em procissão solene, a Deus orando,

Pera os batéis viemos caminhando.

Em tão longo caminho e duvidoso

Por perdidos as gentes nos julgavam,

As mulheres cum choro piedoso,

Os homens com suspiros que arrancavam.

Mães, Esposas, Irmãs, que o temeroso

Amor mais desconfia, acrescentavam

A desesperaçáo e frio medo

De já nos não tornar a ver tão cedo.

Qual vai dizendo: — "Ó filho, a quem eu tinha

Só pera refrigério e doce emparo 
Desta cansada já velhice minha,

Que em choro acabará, penoso e amaro,

Porque me deixas, mísera e mesquinha?

Porque de mi te vás, ó filho caro,

A fazer o funéreo enterramento

Onde sejas de pexes mantimento?"

Qual em cabelo: — "Ó doce e amado esposo,

Sem quem não quis Amor que viver possa,

Porque is aventurar ao mar iroso

Essa vida que é minha e não é vossa?

Como, por um caminho duvidoso,

Vos esquece a afeição tão doce nossa?

Nosso amor, nosso vão contentamento,

Quereis que com as velas leve o vento?”

Nestas e outras palavras que diziam,

De amor e de piadosa humanidade,

Os velhos e os mininos os seguiam,

Em quem menos esforço póe a idade.

Os montes de mais perto respondiam,

Quási movidos de alta piedade;

A branca areia as lágrimas banhavam,

Que em multidão com elas se igualavam.

Nós outros, sem a vista alevantarmos

Nem a mãe, nem a esposa, neste estado,

Por nos não magoarmos, ou mudarmos

Do propósito firme começado,

Determinei de assi nos embarcarmos,

Sem o despedimento costumado,

Que, posto que é de amor usança boa,

A quem se aparta, ou fica, mais magoa.

Mas um velho, d'aspeito venerando,

Que ficava nas praias, entre a gente,

Postos em nós os olhos, meneando

Três vezes a cabeça, descontente,

A voz pesada um pouco alevantando,

Que nós no mar ouvimos claramente,

Cum saber só d' experiência feito,

Tais palavras tirou do experto peito:

— “Ó glória de mandar, ó vã cobiça

Desta vaidade a quem chamamos Fama!

Ó fraudulento gosto, que se atiça 
Cũa aura popular, que honra se chama!

Que castigo tamanho e que justiça

Fazes no peito vão que muito te ama!

Que mortes, que perigos, que tormentas,

Que crueldades neles experimentas!

Dura inquietação d' alma e da vida

Fonte de desemparos e adultérios,

Sagaz consumidora conhecida

De fazendas, de reinos e de impérios!

Chamam-te ilustre, chamam-te subida,

Sendo dina de infames vitupérios;

Chamam-te Fama e Glória soberana,

Nomes com quem se o povo néscio engana!

A que novos desastres determinas

De levar estes Reinos e esta gente?

Que perigos, que mortes lhe destinas,

Debaixo dalgum nome preminente?

Que promessas de reinos e de minas

D' ouro, que lhe farás táo facilmente?

Que fama lhe prometerás? Que histórias?

Que triunfos? Que palmas? Que vitórias?

Mas, ó tu, geração daquele insano

Cujo pecado e desobediência

Náo somente do Reino soberano

Te pôs neste desterro e triste ausência,

Mas inda doutro estado mais que humano,

Da quieta e da simples inocência,

Idade d' ouro, tanto te privou,

Que na de ferro e d' armas te deitou:

Já que nesta gostosa vaidade

Tanto enlevas a leve fantasia,

Já que à bruta crueza e feridade

Puseste nome, esforço e valentia,

Já que prezas em tanta quantidade

O desprezo da vida, que devia

De ser sempre estimada, pois que já

Temeu tanto em perdê-la Quem a dá:

Não tens junto contigo o Ismaelita,

Com quem sempre terás guerras sobejas?

Não segue ele do Arábio a lei maldita,

Se tu pola de Cristo só pelejas? 
Não tem cidades mil, terra infinita,

Se terras e riqueza mais desejas?

Náo é ele por armas esforçado,

Se queres por vitórias ser louvado?

Deixas criar às portas o inimigo,

Por ires buscar outro de tão longe,

Por quem se despovoe o Reino antigo,

Se enfraqueça e se vá deitando a longe;

Buscas o incerto e incógnito perigo

Por que a Fama te exalte e te lisonje

Chamando-te senhor, com larga cópia,

Da Índia, Pérsia, Arábia e de Etiópia.

Oh, maldito o primeiro que, no mundo,

Nas ondas vela pôs em seco lenho!

Dino da eterna pena do Profundo,

Se é justa a justa Lei que sigo e tenho!

Nunca juízo algum, alto e profundo,

Nem cítara sonora ou vivo engenho

Te dê por isso fama nem memória,

Mas contigo se acabe o nome e glória!

Trouxe o filho de Jápeto do Céu

$\mathrm{O}$ fogo que ajuntou ao peito humano,

Fogo que o mundo em armas acendeu,

Em mortes, em desonras (grande engano!).

Quanto milhor nos fora, Prometeu,

E quanto pera o mundo menos dano,

Que a tua estátua ilustre não tivera

Fogo de altos desejos, que a movera!

Não cometera o moço miserando

O carro alto do pai, nem o ar vazio

O grande arquitector co filho, dando

Um, nome ao mar, e o outro, fama ao rio.

Nenhum cometimento alto e nefando

Por fogo, ferro, água, calma e frio,

Deixa intentado a humana geração.

Mísera sorte! Estranha condição!”

IV, 84-104

"Estas sentenças tais o velho honrado

Vociferando estava, quando abrimos

As asas ao sereno e sossegado

Vento, e do porto amado nos partimos. 
E, como é já no mar costume usado, A vela desfraldando, o céu ferimos, Dizendo: - "Boa viagem!"; logo o vento

Nos troncos fez o usado movimento.!"

Mas se esse parentesco intertextual pode provar a fidelidade de Camóes à verdade histórica, pode também comprovar como, pelo recurso ao verosímil, ele foi capaz de dar um corpo, uma voz e um significado "àqueles juízos segundo o que cada um sentia daquela partida" que o cronista menciona, mas náo individualiza nem póe na boca de qualquer personagem que pudesse identificar-se com o "velho de aspecto venerando".

De outras vezes, esse mesmo processo, acrescentando, com perfeita verosimilhança, factos inventados ao real acontecido, permite enriquecer a diegese com traços complementares, mas da maior importância para a constituição, por exemplo, do arquétipo que é o herói colectivo do Poema ou prepara, por contraste, a plena significação de certas figuras. É o que acontece com Fernão Veloso que, emprestando ao tal heróiarquétipo o seu quid de picaresco e de humorístico, prepara, após a referência aos perigos do mar exemplificados na tromba marítima e no fogo de Santelmo, a sequência fulcral, feita de tragédia, épica e lirismo, que é o episódio do Adamastor.

Seguira Camóes, com fiel exactidão, o relato que Castanheda faz, no cap. II do Livro I da História, de uma escaramuça com indígenas no sul da costa ocidental africana, devida à curiosidade aventureira de um dos companheiros do Gama. No Poema o facto transforma-se (V, 27-36) no caso picaresco, graças à imaginação do Poeta que, sem atingir a verdade substancial do acontecido, completa-a pela verosimilhança, ao pôr na boca de Veloso a conhecida bravata, que nenhum outro texto, nem sequer o Roteiro de Álvaro Velho, regista.

Casos há em que a necessidade de recorrer ao valor simbólico de certas sequências narrativas obriga Camóes a faltar por completo à verdade histórica, para, sempre dentro do possível verosímil, enriquecer a diegese de acontecimentos inventados ou deslocados que as fontes históricas lhe não davam. É o que acontece com a tempestade que, no Canto VI (70 e segs.), antecede imediatamente a chegada a Calecute.

Como antes da metamorfose da nuvem no Adamastor, os nautas estão descuidados, ouvindo da boca de Veloso a narração da aventura dos Doze de Inglaterra. Antes da consumação do feito glorioso que era a viagem, importava, porém, na concepção camoniana do heroísmo, fazer sentir aos heróis o travo amargo e a dificuldade do caminho áspero e difícil que precede sempre o encontro com a glória. Mais tarde, na Ilha dos Amores, Vasco da Gama e os companheiros hão-de também subir por um monte espesso, de "mato / Árduo, difícil, duro a humano trato", até atingirem o plano onde refulge o globo cristalino da máquina do mundo (X, 76, 7-8).

A tempestade urdida por Baco no consílio dos deuses marinhos é, por isso, um símbolo da dificuldade inerente à caminhada para a glória.

A realidade histórica da viagem não comportava, porém, aquela dificuldade. Nem por isso o Poeta se lembrou de respeitar a verdade e inventou-a com tanto maior grau de verosimilhança quanto era certo - como refere Castanheda - que, apesar de já ser Inverno naquelas paragens, Deus lhe dera boa ventura: 
"E deu-lhes Deos tão boa ventura que, fazendo já rosto ho inverno da India, pelo que faz naquele golfão grandes tormentas, ele não achou nehũa, antes vento à popa"

(Livro, I, cap. XIII)

Só quando se aproximaram da costa do Malabar sofreram grandes chuvadas e, segundo o Roteiro de Álvaro Velho, algumas trovoadas.

Não creio, ao contrário do que pretende Graça Moura, que seja o Roteiro o hipotexto da tempestade. Vejo-o antes na narração da tormenta que a armada sofrera logo à partida da Angra de S. Brás, que Castanheda refere nestes termos:

"E indo por sua viagem, dia de Santa Luzia, lhe deu hũa grande tormenta de vento à popa com que sofreu o frota todo dia com os traquetes muitos baixos. E nesta rota se perdeu Nicolau Coelho da conservam, e na noite seguinte se y tornou a ajuntar..."

Faria e Sousa, aliás, já relacionara o texto com um passo do cap. III do Livro IV da Década I da Ásia de Barros, onde a tempestade aparece referida. Dissera o cronista:

"Partido deste lugar dia de Nossa Senhora da Conceição, quando se viu ao quarto, que era véspera de Santa Luzia, saltou com ele tấo grande temporal, que per outros tantos dias o fez correr a arvore seca. E como esta era a primeira tormenta, em que os mareantes se tinham visto em mares e climas náo sabidos, andavam tão fora de si, que não havia mais acordo entre eles que clamar por Deus, curando mais na penitencia de seus pecados, que na mareagem das velas, porque tudo era sombra da morte."

Lembremo-nos de que também Vasco da Gama, na estrofe 81, perante tamanho perigo, apela para a "Guarda angélica celeste". No plano da expressão literária, Virgílio e Ariosto lá estavam para lhe fornecerem abundantes formas estilísticas!...

$\mathrm{Na}$ análise intertextual que tenho vindo a fazer, ative-me principalmente a um tipo de verosimilhança factual ou, pelo menos, sempre situada dentro daquele conjunto de acontecimentos reais, cuja ordem, localização no espaço ou situação no tempo o Poeta podia alterar, sem ultrapassar os limites de uma realidade, se não acontecida, pelo menos provável ou possível.

Caberá por isso, com alguma legitimidade, perguntar até onde vão, para Camões, as fronteiras do verosímil credível.

E aqui põe-se-nos com imediata acuidade a questão do maravilhoso!

O recurso ao maravilho estava autorizado (e em tom não menos peremptório!) por Aristóteles, quando na Poética (1460 a) o admitia, com certas limitações na tragédia, mas autorizando-o com tal generosidade na epopeia que permitia atingir as raias do irracional: 
"Ac oportet quidem in tragoediis efficere id quod admirabile est: sed magis in epopeia contingit id quod ratione vocat."

Será, pois, que, em Camóes, o mito se situa ainda no domínio do verosímil possível? Camóes, com efeito, ao enveredar pela exploração estética do fantástico, sem com essa opção pôr em causa a sua fundamental fidelidade à verdade, como que engloba, na força da sua estesia, os mundos possíveis desse fantástico na sua própria realidade mental de criador. E a prova é que, em certas sequências do Poema, a realidade e o fantástico se conjugam com tal harmonia que se fundem numa simbiose onde o leitor, ou pela sua sintonia cultural com o criador, ou por uma espécie de arrastamento empático com que ele o seduz, quase tem dificuldade em destrinçar os dois planos. E foi esse talvez o segredo com que, antecipando-se à crítica vesga de barrocos e neoclássicos, ele conseguiu resolver tão perfeitamente a vexata quaestio da conciliação da mitologia pagã com a essência cristã do Poema.

Podíamos recorrer, para o comprovar, ao conúbio das ninfas e dos nautas nas sombras cúmplices da Ilha Namorada. Mas o exame desse problema exigiria vagares de que náo disponho agora.

Permitam-me chamar a vossa atenção para um outro caso, onde se nota a relevância do papel da mitologia na transformação da história em poesia.

Ao chegarem a Moçamba, conta Castanheda:

"E disseram mais / os visitantes das naus / que apartado dos mouros avia muytos Christãos que moravão sobre si, com que Vasco da Gama folgou muyto, \& então acabou de crer que avia Christãos naquela ilha / .../

Tambem estes nossos / os degredados / forão levados a casa de dous mercadores Indios, parece que Christãos de sam Tomé: que sabendo que os nossos eram christãos mostrarão co’elles muyto prazer, e os abraçarão, e convidarão: \& mostrarão-lhe pintada em hũa carta a figura de Spirito Santo a que adoravão. E perant'elles fizerão sua adoraçáo em giolhos có geito d'omens muyto devotos, \& que tinhão dentro o que mostravão de fora”

A página do cronista é quase só metrificada nas estrofes 5 a 15 do Canto II, e o engano dos falsos cristãos preparados pelo Rei de Moçambique aparece no Poema atribuído à mesquinha emulação de Baco que

"Estava nũa casa da cidade,

Com rosto humano e hábito fingido,

Mostrando-se Cristão, e fabricava

Um altar sumptuoso que adorava.

Ali tinha em retrato afigurada

Do alto e Santo Espírito a pintura,

A cândida pombinha, debuxada

Sobre a única Fénix, Virgem pura."

E diante do altar, cujo retábulo figurava o Pentecostes, logo nos lembramos como "o falso deus adorava o verdadeiro". 
Todos sabemos também como, levado pelo engano, Vasco da Gama determina que a armada entrasse no porto e como, pela força das correntes, os mouros, julgando descoberta a cilada, se precipitam no mar. O passo vem também narrado em Barros e Castanheda.

A convizinhança das divindades com a Trindade Santíssima dos Cristãos redundava na sujeição das primeiras à segunda!

E é deste modo que o verosímil acaba por abarcar, sem choque nem incongruência, mesmo para os ouvidos pios dos censores inquisitoriais, a própria alegoria mitológica, como já afirmou, embora por linhas travessas, o responsável pela editio princeps das Rimas, de 1595, fosse ele ou não Fernáo Rodrigues Lobo Soropita, quando diz:

"y en las ficciones alegoricas (sin las cuales no puede haver Poema Heroico, según la opinión de Aristoteles, y de Plutarco, repreendiendo a Emédocles, Parménides, Nicandro y Teógnides, de que usurpassen el nombre de Poetas con versos desnudos de ficciones aúnque ricos de doctrina), mostró (su Poeta, já se vê) un ingenio tan admirable, que casi se iguala a Homero".

Daí que a alegoria mitológica se incorpore, no imaginário do Poeta, no corpo possível das verosimilhanças. E com tal força ou ilusão que Faria e Sousa, ao comentar as estrofes XXI a XXIV do Canto I, não hesita em afirmar:

"Por los siete planetas que el Poeta finge, acudieron al concilio, prosiguiendo en nuestra segurisima alegoría que descubrimos se pueden entender muchas cosas, i principalmente las que en la religión católica se reduzen a este numero septenario misterioso: como serán los Sacramentos della, que con esta acción se pretendían passar a la Índia, las siete virtudes, i los siete Dones"

Deste modo Júpiter é “el sumo Dios, uno i trino, i singularmente a Cristo”; Vénus, ora representa a Igreja, ora Nossa Senhora; Ninfas e Musas personificam virtudes e anjos. Baco, "el Infierno junto, i con singularidad a su Principe Infernal", ou então Mafoma...

A ousadia hermenêutica de Faria e Sousa era tal que a Inquisição arreganhou o dente, valendo-lhe o testemunho amigo de D. Tomás Tamayo de Vargas...

A verdade exigida por um conceito de épica talhado pela justa medida do humano, e pela credibilidade imprescindível à função pedagógica da poesia conciliava-se, na mente do criador, com a estesia nele provocada pelo seu próprio texto. E o verosímil aristotélico, graças à sua interpretação, não tinha dificuldade nem escrúpulo em considerar como possíveis os mundos da fantasia, mesmo mitológica, como expressão suprema de uma capacidade estética onde vivência e cultura se fundiam no todo inconsútil do discurso poético. 